\title{
Üniversite Kütüphanelerinde Halkla İlişkiler ve Başkent Üniversitesi Kütüphanesi ${ }^{*}$
}

\author{
Public Relations at University Libraries and Başkent \\ University Library
}

\author{
Nermin Gül ÇAĞLAR* ve Bülent YILMAZ ${ }^{* * *}$
}

\begin{abstract}
Öz
Halkla ilişkiler, bir kurumun hizmet verdiği kitlenin güven, sempati ve desteğini elde etmek ve bunu sürdürmek için gerçekleştirdiği etkinliklerin tümüne denir. Üniversite kütüphanelerinde halkla ilişkiler çalışmalarının amacı, kullanıcıların kütüphaneye karşı olumlu düşüncelere sahip olmalarını sağlamaktır. Bir üniversite kütüphanesinde halkla ilişkiler çalışmalarının durumunu belirlemek, bu konudaki sorunlara yönelik çözümler üretilmesi ve halkla ilişkilerin geliştirilmesi açısından büyük önem taşımaktadır. Bu çalışma, Başkent Üniversitesi Kütüphanesi kullanıcılarının halkla ilişkilere yönelik kütüphane hakkındaki düşüncelerini ortaya koymak amacıyla yapılmıştır. Çalışma, Başkent Üniversitesi Kütüphanesi'ni kullanan 200 öğrenci ve akademik personele uygulanarak gerçekleştirilmiştir. Ayrıca, Başkent Üniversitesi Kütüphanesi'nin halkla ilişkiler etkinlikleri ile ilgili kişisel gözlemlerde de bulunulmuştur. Araştırma sonucunda, Başkent Üniversitesi Kütüphanesi'nin gerçekleştirdiği halkla ilişkiler etkinliklerinin kısmen yeterli olduğu anlaşılmıştır.
\end{abstract}

Anahtar sözcükler: Halkla ilişkiler, Üniversite Kütüphaneleri, Başkent Üniversitesi Kütüphanesi.

\section{Abstract}

Public relations is the sum of all activities of an institution to gain in a permanent way the trust, sympathy and support of target mass. The objective of the public relations department in the libraries is to make

\footnotetext{
"Bu makale, Nermin Gül Çağlar’ın yüksek lisans tezine (Çağlar, 2006) dayanmaktadır.

**ütüphaneci. Başkent Üniversitesi Kütüphanesi (nerming@baskent.edu.tr).

Prof. Dr. Hacettepe Üniversitesi Edebiyat Fakültesi Bilgi ve Belge Yönetimi Bölümü öğretim üyesi (byilmaz@hacettepe.edu.tr).
} 
people to gain positive opinions on the library. Determining the situation of the public relations effort at the university library and creating the solutions for the problems and developing the ways and means of the public relations work are very important. This study aims to clarify the opinions of the Başkent University Library users about public relations efforts of the library. The study is conducted on 200 respondents who are academic staff and students of the Başkent University and also the users of library. In the study, there are also observations about the activities of the Başkent University Library on public relations. Conclusively seems that the public relations activities of the Başkent University Library are partially sufficient.

Keywords: Public relations, University libraries, Başkent University Library.

\section{Giriş}

Çağımızda, örgütler varlıklarını sürdürebilmeleri, kendilerini içinde bulundukları çevreye kabul ettirebilmeleri ve toplumun gereksinimlerine yanıt verebilmeleri için, etkili halkla ilişkiler uygulamalarına gerek duymaktadır. İnsanların istek ve gereksinimlerinin giderilmesi ve tatmin edilmesi ile kişilerin, işletmelerin, kurum ve kuruluşların karşılıklı ilişkileri iletişime bağlıdır. Dolayısıyla, halkla ilişkiler, kişiler ve kuruluşlar arasındaki ilişkilerin kurulması ve yönetilmesinde büyük önem taşımaktadır (Tengilimoğlu ve Öztürk, 2004, s. 21).

Halkla ilişkiler, bir anlamda, kurumların hizmet sundukları kitle ile iletişim kurma sürecidir. Bu sürecin temel hedefi, bu kitleleri kurum hakkında bilgilendirerek, kuruma yönelik güven, ilgi, sempati gibi olumlu düşünceler yaratmak ve böylece kurumun gelişmesi ve güçlenmesine anlamlı katkılar sağlamaktır. Halkla ilişkiler çalışmaları ile kurumun yönetimine ve hizmetlerin geliştirilmesine hedef kitlenin katılımını sağlama, örgüt kültürü oluşturma, kuruma ilişkin olumlu bir imaj yaratma, hedef kitle ve yönetimden destek bulma, doğru yönetim politikaları oluşturma, sunulan hizmette verimlilik sağlama gibi önemli yararlar elde edilebilir. Bir kurumun halkla ilişkiler uygulamalarını tam olarak gerçekleştirebilmesi durumunda "iyi" bir kurum olma olasıığı artar ve bu süreçte halkla ilişkiler anlamlı rol oynar ve katkı sağlar. Özellikle, toplumların demokratik sistemlerde yaşama eğilimleri, bilgisayar, televizyon gibi gelişmiş teknolojik araçların ortaya çıkması, kurumların kendilerini, içinde bulundukları toplumlara kabul ettirme (meşruiyet) zorunluluklarının artması, rekabet olgusunun güçlenmesi, küreselleşme 
gibi değişimlerin yaşanması halkla ilişkilerin çağdaş varlık nedenleri olarak düşünülebilir (Biber, 2004). Ayrıca, halkla ilişkiler çalışmalarının yönetim olgusunun organik bir parçası olduğu, yönetimin bulunduğu her yerde halkla ilişkilerin de olacağı gerçeği kabul edilmektedir. Kısaca, kurumların, etkili ve verimli bir yönetim için çeşitli nitelikteki araçlarla hizmet verdiği kitle ile iyi ilişkiler kurarak fikirlerinin alınması, onlarda kuruma ilişkin olumlu düşünceler yaratılması, kurum hakkında bilgilendirilmesi ve gelişmelerden haberdar edilmesi gerekli ve önemlidir.

Üniversiteler, en üst düzeyde eğitim-öğretim etkinlikleri ile bilimsel araştırmalar yapan kurumlardır. Eğitim-öğretim ve araştırma etkinlikleri, özellikle "bilgi toplumu" olarak adlandırılan günümüz toplumlarında gelişmişliğin temel ölçütleri arasında sayılmaktadır. Dolayısıyla, üniversiteler toplumsal gelişmeye liderlik eden başlıca kurumlar arasında yer almaktadır. Bilgi üretme sürecinin başlıca özneleri olan üniversitelerin gerek eğitim-öğretim gerekse araştırma işlevlerini yerine getirmede gereksinim duydukları temel kurumlardan birisi üniversite kütüphaneleridir. Kütüphanesi işlevsel olmayan bir üniversitenin verimli biçimde eğitim-öğretim ve araştırma etkinliklerini sürdürmesi olası değildir. Üniversitelerin, bilgi üretme hedefini gerçekleştirmesinde bilgiyi elde eden, ve bu bilgileri düzenleyerek kullanıcıların gereksinimlerine sunan kütüphaneler, üniversiteler için zorunlu ve aynı zamanda organik altyapı kurumlarıdır.

Kütüphanelerde halkla ilişkilerin amacı, kütüphaneyi ve sunulan hizmetleri tanıtmak ve bu hizmetlerin kullanımını artırmak için çalışmalar yapmak, bilgi kaynaklarının kullanımı ile ilgili bilgiler vermek, kullanıcılarla sürekli iyi ilişkiler kurmak, onların kütüphane ve kaynaklar hakkındaki düşüncelerini öğrenmektir (Guinchat ve Meneoe, 1990, s. 309).

Türkiye'de kütüphanelerde halkla ilişkiler konusunda çeşitli çalışmalar yapılmıştır. Ayrıca, Türk kütüphanecilik literatüründe bu konuda yapılan ve tez düzeyinde olan sınırlı sayıda çalışma göze çarpmaktadır. Bunlardan ilki; halk kütüphanelerinde halkla ilişkiler konusunun ele alındığı "Türkiye'deki Halk Kütüphaneleri ve Halkla İlişkiler" (Fındık, 1985) adlı doktora tezidir. İkinci çalışma; "Kütüphanecilikte Halkla İlişkiler ve Kitle İletişim Araçları" (Yılmaz, 1996) adlı yüksek lisans tezidir. Bu çalışmada, kütüphanecilikte halkla ilişkiler konusu genel olarak ele alınmış ve özellikle kitle iletişim araçları ve kütüphanelerin bu araçlardan yararlanma olanakları incelenmiştir. Diğer bir çalışma; "Üniversite Kütüphanelerinde Halkla İlişkiler ve Türkiye'de 
Durum" (Kayan, 1996) adlı yüksek lisans tezidir. Bu tezde, üniversite kütüphaneleri ve Türkiye'deki üniversite kütüphanelerinin halkla ilişkiler açısından durumları genel olarak incelenmiş ve bu konuda Türkiye'deki üniversite kütüphane yöneticilerinin fikirleri değerlendirilmiştir. Dördüncü çalışma ise; Bilkent Üniversitesi Kütüphanesi'ni kullanan lisans ve yüksek lisans öğrencilerinin görüşlerinin yer aldığı "Üniversite Kütüphanelerinde Halkla İlişkiler ve Bilkent Üniversitesi Kütüphanesi” (Sönmez, 2000) adlı yüksek lisans tezidir.

\section{Halkla İlişkiler: Tanım}

Literatürde halkla ilişkiler konusunda yapılmış çeşitli tanımlamalara rastlanmaktadır. Buna göre halkla ilişkiler;

$>$ Belirli grupları etkilemek amacıyla planlanmış bir haberleşme aracıdır (Marston,1963, s. 3).

> Bir kuruluşu bünyesinde çalışanlara, müşterilere, bağıntılı olduğu kişilere sevdirme ve saydırma sanatıdır (Marston, 1963, s. 3).

$>\quad$ Özel ya da tüzel kişinin, yani bir insanın, derneğin, özel ya da kamu kuruluşunun karşılıklı iş yaptığı gruplarla ilişkiler kurması, varsa ilişkilerini geliştirmesi için gösterilecek çabalardır (Asna, 1997, s. 208).

$>$ Kişinin ya da bir kurumun halkla ilgisini geliştirme ve anlama yolundaki çabadır (Tortop, 2003, s. 14).

> Kişi ya da kuruluşun, diğer kişi ya da kuruluşlarla bir çıkar elde etmek amacıyla ilişkiler kurmak veya var olan ilişkilerini geliştirmek için gerçekleştirdiği faaliyetlerin tamamıdır (Budak ve Budak, 2004, S. 8).

> Halkla ilişkiler örgütle/kurumla hedef kitlesinin karşılıklı olarak birbirlerinin gereksinimlerine uyum sağlayacak şekilde yardımlaşmasıdır (Lesly, 1989, s. 5).

"Uluslararası Halkla İlişkiler Birliği" (International Public Relations Association-IPRA) nin tanımı ise şöyledir: Halkla ilişkiler bir işletmenin ya da özel veya kamusal bir kuruluşun bağlantı kurduğu veya kurabileceği kimselerin anlayış, sempati ve desteğini elde etmek ve bunu devam ettirmek için yaptığı sürekli ve örgütlenmiş bir yönetim görevidir (Onal, 1997, s. 9).

Halkla ilişkiler 20.yüzyılın bir olgusu olarak görülmekle birlikte, gerçekte tarihin çok eski dönemlerine kadar uzanmaktadır. (Peltekoğlu, 1993, s. 11; Erdoğan, 2006, s. 19). Halkla ilişkilerle ilgilenen 
araştırmacılar, halkla ilişkilerin insanların toplum halinde yaşamaya başlamalarından beri var olduğunu kabul etmektedirler (Tortop, 2003, s. 22). Halkla ilişkiler teriminin ilk kez ve kimin tarafından kullanıldığı ise tartışmalı bir konudur. İngiltere Halkla İlişkiler Enstitüsü Müdürü Paget Cook'a göre, terim ilk kez Thomas Jefferson'un 1807'de 10. Kongreye gönderdiği bir mesajda Amerika Birleşik Devletleri'nin dış ilişkileri ile ilgili olarak kullanılmıştır (Şen ve Çerçi, 1976, s. 15;). Tüm bu tartışmaların dışında halkla ilişkilerin anavatanının Amerika Birleşik Devletleri olduğu ve modern halkla ilişkiler mesleğinin doğuşunun dünyadaki ekonomik ve sosyal gelişmelerle yakından ilgili olduğu söylenebilir (Şen ve Çerçi, 1976, s. 15). Halkla ilişkiler çalışmalarının sistematik bir kimliğe bürünmesi 19. yüzyılın ikinci yarısına rastlamaktadır. 1896 yılındaki ABD seçim kampanyasında, Bryan ve Mc Kinley mücadelesi, siyasal arenada halkla ilişkilerin örgütlü bir biçimde kullanılmasının ilk örneği olmuştur (Bıçakçı, 1998, s. 122). Bu çalışmalar zamanla çeşitli iş sektörlerinde de görülmeye başlanmıştır. 1900'lerden sonra iş dünyasının yeni yasal düzenlemelere uymak durumunda olması ve basının katı eleştirilerine maruz kalması, 20. yüzyılın büyük kuruluşlarında halkla ilişkileri zorunlu kılmıştır. Sözü edilen kuruluşlar daha önceki uygulamalarının olumsuz imajlarını silmek için "halkın aydınlatılmasını" temel alan yeni bir halkla ilişkiler anlayışını oluşturmaya başlamıştır (Peltekoğlu, 1993, s.15). 1955 yılında Norveç, Hollanda, Fransa, Amerika Birleşik Devletleri ve İngiltere'nin girişimleriyle Uluslararası Halkla İlişkiler Derneği kurulmuştur (Black, 1993, s. 181). Ayrıca, Amerikan Halkla İlişkiler Birliği, Amerikan Halkla Illişkiler Derneği, Ekonomik Halkla İlişkiler Derneği, Demiryolu Halkla İlişkiler Derneği gibi çeşitli konularla ilgili halkla ilişkiler dernekleri de kurulmuştur (Tortop, 2003, s. 26). Görüldüğü gibi, halkla ilişkiler çalışmalarının güçlü bir tarihsel gelişim gösterdiği söylenebilir.

\section{Halkla İlişkilerde Amaçlar, İşlevler ve Temel İlkeler}

Halkla ilişkilerin amaçları;

Halkı aydınlatmak ve örgütün çalışmalarını onlara benimsetmek,

> Halkın yönetime karşı olumlu tavırlar geliştirmesini sağlamak,

$>\quad$ Halkın yönetimle olan işlerini kolaylaştırmak,

> Alınacak kararların daha isabetli olması için halktan bilgi almak,

$>\quad$ Halkla işbirliği içinde olmak, böylece de hizmetlerin daha çabuk ve kolay görülmesini sağlamak, 
$>$ Yasaklar hakkında aydınlatıcı bilgiler vererek halkın yasalara uymasını sağlamak,

> Yasalarda ve yönetsel işlerdeki aksaklıkların giderilmesinde halkın dilek, istek ve şikâyetlerinden yararlanmak, biçiminde sıralanabilir.

Halkla ilişkilerin işlevleri ise;

$>$ Katılımcılığın sağlanması,

$>\quad$ Örgüt kültürünün oluşturulması ve benimsetilmesi,

> Tanınma ve tanıtma çalışmalarında eşgüdümün sağlanması,

$>\quad$ Olumlu bir örgüt imajının oluşturulması,

$>$ Siyasal destek sağlanması,

$>\quad$ Nitelikli insan kaynağının sağlanması,

$>$ Yönetsel politikaların oluşturulması,

$>$ Toplumsal değişimin yönünün belirlenmesidir.

Halkla ilişkilerde temel ilkeleri aşağıdaki gibi sıralamak olanaklıdır:

$>\quad$ Halkla ilişkiler iki yönlü bir iletişim sürecidir.

$>\quad$ Halkla ilişkiler gerçekleri yansıtan dürüst bir uygulamadır.

$>\quad$ Halkla ilişkiler sabır isteyen sürekli bir çalışmadır.

$>\quad$ Halkla ilişkiler inandırıcılığa dayalıdır.

> Halkla ilişkiler bir uzmanlık işidir (Onal, 1997, s. 32-33).

\section{Halkla İlişkiler Çalışmasında Aşamalar ve Kullanılan Araçlar}

Halkla ilişkiler çalışmasının genelde dört aşamadan oluştuğu söylenebilir.

1. Bilgi Toplama-Araştırma: Bilgi toplama-araştırma, halkla ilişkiler çalışmalarındaki ilk aşamadır. Bir kurum için gerekli bilgiler toplanırken ve araştırma yapılırken kurumun özellikleri ve yaşanan sorunlar öncelikle dikkate alınmalıdır. Halkla ilişkilerde önemli olan hedef kitleyi tanıyıp, onların eğitim, gelenek, alışkanlık, görüş, inanç ve tüm yöresel özelliklerini çok iyi bilmek, araştırmanın başarılı bir biçimde ortaya çıkmasını sağlayacaktır. Bu aşamada, bilgilerin toplanmasında çeşitli yöntemler kullanılmaktadır. Bunlar; "İ̧̧letme içi araştırmalarda işletme raporları, kayıtlar, tutanaklar, mektuplar, personelin görüş ve önerileri, halkla ilişkiler uzmanının izlenim ve önsezileri birer bilgi kaynağı olarak kullanıı" (Sabuncuoğlu, 2004, s. 93).

2. Planlama: Halkla ilişkiler, amaçlı bir araştırmanın başarıyla sonlandırıması, örgüt-çevre ilişkisinde ne tür sorunların yaşandığının 
ve bu sorunların nerelerden kaynaklandığının belirlenmesi anlamına gelmektedir. Dolayısıyla bu aşamadan sonra, sorunların aşıımasına veya ortada herhangi bir sorun yoksa mevcut durumun sürdürülmesine yönelik kararlar alınmalıdır. Sorunların çözümüne yönelik kararlar almak, örgütün geleceğiyle ilgili planlar yapmak demektir. Çünkü, planlama çalışmasıyla nereye, nasıl, hangi maliyetle, hangi sürede, kiminle ulaşılmak istenildiğine karar verilmelidir (Harrison, 1995, s. 47; Jefkins, 1974, s. 211).

3. Uygulama; Araştırma ve planlama süreci sonrasında gerçekleşen ve halkla ilişkilerin en zor aşamalarından birisi uygulamadır. Bu aşamada kaynakların ve hedeflerin belirlenmesinin (planlama) yanı sıra, hangi uygulamaların hangi sürede tamamlanacağına ve bunlardan kimlerin sorumlu olacağına karar verilir. Uygulama aşaması bütün örgütün katkılarıyla ve büyük bir titizlikle gerçekleştirilmelidir. Aksi takdirde, araştırma ve planlama aşamasındaki çalışmalar boşa gitmiş olur. Yani, bu aşamada halkla ilişkiler çalışanlarına, üst düzey yöneticilerine ve bütün personele çok büyük sorumluluklar düşmektedir (Sabuncuoğlu, 2004, s. 103).

4. Değerlendirme: Halkla ilişkiler çalışmaları, planlama sürecinde belirlenen işlerin doğru ve başarılı bir şekilde uygulanması sonrasında değerlendirme ile tamamlanır. Bu aşamada yapılan değerlendirmenin sonuçlarına göre, amaçlara ulaşılıp ulaşılamadığı, karşılaşılan eksikliklerin ve sorunların belirlenmesine çalışılmaktadır. Uygulamada herhangi bir sorun ve aksaklık varsa, halkla ilişkiler sürecinin başına yani araştırma aşamasına geri dönülür. Değerlendirme örgüt için daha sonraki çalışmalara hazırlık olması açısından önem taşır (Yapar, 1999, s. 20).

Halkla ilişkilerde kullanılan iletişim araçları yazılı, sözlü ve görsel-işitsel araçlar olmak üzere üç bölümde ele alınabilir.

1. Yazılı İletişim Araçları: Gazeteler, dergiler, broşürler ve el kitapları, yıllık raporlar, afişler, pankartlar ve el ilanları.

2. Sözlü İletişim Araçları: Yüz yüze ve telefon görüşmeleri, toplantılar, konferans ve seminerler.

3. Görsel ve İşitsel İletişim Araçları: Radyo ve televizyon, film ve videokasetleri, sergiler, fuarlar ve yarışmalar, açılışlar, yıldönümleri ve törenlerdir. 


\section{Üniversite Kütüphanelerinde Halkla İlişkiler}

Halkla ilişkilerin, \%90 performans gösterme, \%10 yorum yapma olduğu, dolayısıyla, bu çalışmaların büyük çaba gerektirdiği söylenebilir. Bir başka deyişle, halkla ilişkilerde söylenen değil yapılan önemlidir. Amaç iyi hizmet vermek, iyi iş yapmak ve yapılanları halka anlatmaktır. Bu bağlamda halkla ilişkiler kütüphane yönetiminin işleyen bir parçasıdır (Simmons, 1989, s. 187). Üniversite kütüphaneleri, bünyesindeki memnuniyeti dışarı taşımak istediğinde halkla ilişkiler devreye girmektedir. Halkla ilişkiler çalışmalarında öğrenciler, öğretim üyeleri, araştırma görevlileri ve üniversitenin diğer elemanlarının kütüphaneyi kullanmalarına yardımcı olunması amaçlanır. Halkla ilişkiler sadece danışma masası ile sınırlı değildir. Yönetimden temizlik görevlilerine kadar herkesin içinde olduğu bir yapıdır. Kütüphanenin kullanıcılardaki iyi imajı, danışma masasında sorulan soruları yanıtlayan görevli, kapıdaki güvenlik, temizlik görevlilerinin giyimi, çalışanların kendilerini işe vermeleri ve işle bütünleşmiş duyumsamaları ile sağlanır (Emezi, 1972, s. 30). Üniversite kütüphanelerinde etkili halkla ilişkiler kütüphane personeli, öğretim üyeleri ve öğrenciler arasındaki iletişimin gelişmesiyle artacaktır (Ford, 1985, s. 400). Kütüphane dışı ilişkilerde, öğrenciler ve öğretim üyeleri ve diğer kullanıcılar ile yakın ilişki sağlanmalıdır. Bu, kütüphanenin kuruluşunun amacı olan isteğe hizmettir. Kütüphanenin uyandırdığı/yansıttığı ilk iyi izlenim, ondan eğitim için gerekli şekilde yararlanmayı sağlarken, kötü izlenimleri silmek ise zordur. Kütüphane ve kullanıcılar arasında iyi ilişkiler kurmak ve bu ilişkileri sürdürebilmek halkla ilişkilerde en önemli amaçtır. Halkla ilişkilerin temelini de iyi insan ilişkileri oluşturur. Kütüphanede çalışan gerek kütüphaneci ve gerekse kütüphaneci olmayan personelin kullanıcılara karşı nazik, sabırlı, iyi niyetli davranmaları ve onlara yardımcı olmaları, kütüphanecilikte halkla ilişkilerin birincil unsurudur. Etkili insan ilişkileri açısından, özellikle kütüphaneye ilk defa gelmiş yeni kullanıcılara kütüphane tanıtılmalı, verilen hizmetler ve olanaklar anlatılmalıdır. Halkla ilişkilerde önemli olan, yapılan işleri farklı göstermek ya da kusurları örtmek değildir. Kütüphane, kullanıcılarının güvenini ve hoşgörüsünü kazanarak, daha iyi hizmetler verme amacında olduğunu göstermelidir (Fındık, 1988, ss. 6970). Halkla ilişkiler çalışmalarında kullanıcılarla personel arasındaki iletişimin olumlu olması gerekmektedir. Üniversite kütüphanecilerinin, araştırıcının gereksinim duyduğu ya da duyabileceği bilgilere erişebilmesi için araştırma yapanlarla mutlaka işbirliği içinde olmaları 
gerekmektedir. Bir üniversite kütüphanecisi genel olarak halkla ilişkiler bağlamında şunları yapmalıdır:

Gereksinim duyan kullanıcılara bilgiye nasıl ulaşılacağını öğretmeli,

$>\quad$ Kullanıcıların gereksinim duyduğu ya da duyacağı varsayılan bilgi kaynaklarını izlemeli,

$>$ Kullanıcıları gereksinim duydukları konularda haberdar etmeli,

$>$ Bilgi kaynaklarını araştırıp, kullanıcının konusuyla ilgili olanların seçilmesinde ona rehberlik etmeli,

$>$ Kullanıcının, gereksinim duyduğu bilgiye hızla ve kolayca erişmesini sağlamak amacıyla, gerekli araç, gereç ile yöntemleri belirlemeli, bu çerçevede gerekli düzenlemeleri yapmalıdır.

Dolayısıyla, üniversite kütüphanecisine günümüzde daha fazla sorumluluk yüklenmiştir. Özellikle, kütüphaneciler araştırmayı gerektiren yeni sorumluluklar almaktadırlar. Bu sorumluluklar için; üniversite düzeyinde eğitim görmüş, konusunda uzman, kullanıcının ve çalıştığı kütüphanenin bilgi erişim sorunlarına bilimsel olarak yaklaşabilen, üniversitenin diğer akademik birimleriyle ortak çalışmalar yürütebilen, işbirliği yapabilen kütüphanecilere gereksinim duyulmaktadır (Tunçkanat, 1989 , s. 191). Kısaca, halkla ilişkiler konusunda bilgili ve tecrübeli kütüphanecilerin görev yapması büyük önem taşımaktadır.

\section{Başkent Üniversitesi Kütüphanesi}

Başkent Üniversitesi (BÜ) Kütüphanesi 1993 yılında, önceleri, dergilerin toplanarak doktorların kullanımına sunulmasıyla hizmet vermeye başlamış, özellikle bağış kitaplarla dermesini oluşturmaya çalışmıştır. 1995 yılında şu an hizmet vermekte olduğu Bağlıca Kampusu'na taşınmıştır (Arda, 2000, s. 12). Kütüphane $1000 \mathrm{~m} 2$ lik bir salonda hizmete başlamış, ancak bu alan zamanla gereksinimlere yetmediği için, mevcut alana süreli yayınlar ve danışma birimleri için $2000 \mathrm{~m} 2$ lik bir alan daha eklenerek, hizmet alanı toplam 3000 m2'ye çıkarılmıştır.

BÜ Kütüphanesi'nde; sağlama, süreli yayınlar, sınıflama ve kataloglama işlemleri, okuyucu, ödünç verme ve danışma hizmetleri ile otomasyon uygulamaları yürütülmektedir.

\section{BÜ Kütüphanesi Toplam Kalite Yönetimi Çalışmalan ve Uygulamalan}

Başkent Üniversitesi'nin tüm bölüm ve birimlerinde devam eden "Toplam Kalite Yönetimi” çalışmaları kapsamında; kütüphanede gerek personelin sürekli eğitimi, gerekse bu çerçevede işlerin izlenmesi, sorunların 
belirlenmesi, hataların önlenmesi ve hizmetlerin daha iyiye götürülmesi için çalışmalar yürütülmektedir. Başkent Üniversitesi'ndeki TS-EN-ISO 9000 çalışmaları kendi bünyesinde bulunan Toplam Kalite Yönetim Merkezi tarafından koordine edilmiştir. 23-25 Aralık 1997 tarihleri arasında Türk Standartları Enstitüsü'nde TS-EN-ISO 9000 hakkında kütüphaneden de bir personelin katıldığı üç günlük eğitim semineri düzenlenmiştir. Daha sonra kütüphanedeki bütün personele bu konuda eğitim verilmiş ve çalışmalar başlatılmıştır. Bu kapsamda, kütüphanede yapılan işler, verilen hizmetler belirlenmiş, birimlerin sorumluları hizmet prosedürlerini ve görev yönetmeliklerini oluşturmuşlardır (Çınar, 1998, s. 71). BÜ ve Kütüphanesi'nde TSE tarafından son yayınlanan ISO 9001:2000 standardı uygulanmaktadır. Bu standart kurumsal kalitenin geliştirilmesi ve sürdürebilirliğinin sağlanmasında bazı ilkeleri göstermektedir. TS EN ISO 9001 2000'den aktaran Külcü (2005, s. 32), bu ilkeleri şöyle sıralamaktadır: "Kalite yönetim sistemleri, dokümantasyon şartları ve doküman kontrolü, yönetim sorumluluğu, yetki ve iletişim, yönetimin gözden geçirilmesi, kaynak yönetimi, ürün gerçekleştirme, tasarım ve geliştirme, satın alma, üretim ve hizmetlerin sağlanması, ölçme analiz ve iyileştirme, veri analizi ve önleyici faaliyetlerden oluşmaktadır". Bu standart kapsamında BÜ Kütüphanesi'nde sürekli gelişme ve iyileştirme etkinlikleri, müşteri memnuniyetini içine alan uygulamalar ve belgeleme çalışmaları yürütülmektedir. ISO 9001:2000 revizyonunda ise, sürekli iyileştirme kavramı geniş bir biçimde ele alınmıştır. BÜ Kütüphanesi'nde bu kapsamda her yıl kalite hedefleri belirlenmekte ve bu hedefler altı ayda bir gözden geçirilmektedir. Yılsonu hedeflere ulaşılıp ulaşılamadığı ölçülerek analiz edilmekte ve analiz sonuçlarına göre öneriler getirilmektedir.

\section{Başkent Üniversitesi Kütüphanesinde Halkla İlişkiler Uygulamaları}

Başkent Üniversitesi Kütüphanesi'nde ayrı bir halkla ilişkiler bölümü ve uzmanı bulunmamakta, dolayısıyla bir halkla ilişkiler programı planlanması da yapılmamaktadır. Buna karşın kütüphane ve hizmetlerinin tanıtımı amacıyla bazı etkinlikler yürütülmektedir.

Başkent Üniversitesi Kütüphanesi'nde halkla ilişkiler etkinliklerine yönelik çeşitli araçlar kullanılmakta ve farklı hizmetler verilmektedir. Bunlar: Yer gösteren kütüphane tabelaları, raf yönlendirmeleri, şikâyet defteri, şikâyet-dilek kutusu, duyuru panoları, uyarı yazıları, çeşitli biçimlerde yapılan kütüphane tanıtım ve duyuru hizmetleri ve çevrimiçi katalog programı gibi araçlar ve hizmetlerdir. Kullanıcıların kütüphanede yapılan işlem ve 
hizmetler hakkında fikirlerini almak amacıyla belirli zamanlarda anketler de uygulanmaktadır.

Kütüphanede yazılı halkla ilişkiler araçlarından broşür, afiş, gazete, dergi, yıllık rapor ve benzerleri tercih edilmektedir. Mektup ve bayram kartları gibi yazılı araçların kullanımı da kurumlarla ve kullanıcılarla iletişim açısından önemlidir. Kullanıcılarla kütüphane çalışanları gerektiğinde yüz yüze, ya da telefonla görüşebilmektedirler. Kütüphanede zaman zaman personel ve kullanıcılara yönelik olarak çeşitli veri tabanlarının kullanımı ve tanıtımı için toplantılar ve seminerler düzenlenmektedir. Kütüphane için radyo, televizyon, film, videokaset, sergi, fuar, yarışma, açılış ve yıldönümü törenleri gibi görselişitsel halkla ilişkiler araçları genellikle kullanılmamaktadır. Ancak, halkla ilişkiler için önem taşıyan aydınlatma, temizlik, düzen, ısınma gibi diğer unsurlara da dikkat edilmektedir. BÜ Kütüphanesi'nde aydınlatma beyaz ışıklarla yapılmaktadır. Isınma kütüphane için yeterli olup, yerler halı kaplıdır. Kütüphanenin temizliğine özen gösterilmekte, günlük ve haftalık olarak genel temizlik yapılmaktadır.

\section{Araştırmanın Kapsamı ve Yöntemi}

"BÜ Kütüphanesi'nde gerçekleştirilen halkla ilişkiler çalışmalarını kullanıcı görüşleri ve gözlemlerimize dayanarak değerlendirmek, varsa yetersizlikleri ve bunların nedenlerini ortaya çıkarmak" amacı ile yapılan araştırmanın evrenini; BÜ Kütüphanesi'ni kullanan öğretim üyeleri (profesör, doçent, yardımcı doçent), öğretim üye yardımcıları (araştırma görevlileri, öğretim görevlileri, okutman ve uzmanlar) ile lisans ve yüksek lisans öğrencileri oluşturmuştur. Çalışmada BÜ'ne kurumsal bağlantıları bulunmadığı için "dış kullanıcılar" (BÜ öğretim elemanı ve öğrencisi olmayanlar) ile eğitim ve araştırma etkinliğiyle doğrudan ilgisi bulunmayan idari personel, kapsam dışı tutulmuştur. Bu durumda araştırma evreninin kapsadığı kullanıcı sayısı 9215'dir' ${ }^{1}$. Çıngı'ya (1990, s.261) göre, 0,99 güven düzeyi $\pm 0,04$ hoşgörü miktarına göre evreni temsil etmesi gereken örneklem sayısı 194'dür. Çalışmada evren 200 kullanıcı ile örneklendiğinden, örneklem evreni temsil etmektedir. Araştırmada betimleme yöntemi kullanıımıştır. Anket uygulaması sırasında kütüphane kullanıcıları ve BÜ Halkla îlişkiler Bölümü’nden ilgili kişilerle yüz yüze görüşmeler yapılmıştır.

${ }^{1}$ BÜ Personel Daire Başkanlığı ve Öğrenci İşleri Daire Başkanlığı'ndan Aralık 2005 tarihinde alınan bilgi. 


\section{Bulgular ve Değerlendirme ${ }^{2}$}

$\mathrm{Bu}$ bölümde, kullanıcılardan anket yoluyla elde edilen bazı veriler değerlendirilerek, yorumlanmaktadır.

\section{Kullanıcıların BÜ Kütüphanesi'ni Kullanmayı Öğrenme Biçimleri}

Halkla ilişkiler etkinliklerinin amaçları arasında bulunması nedeniyle, kullanıcıların kütüphaneyi kullanmayı öğrenmelerinde BÜ Kütüphanesi halkla ilişkiler çalışmalarının etkili olup olmadığı araştırma konusu açısından önem taşımaktadır. Bu çalışmalar çerçevesinde BÜ Kütüphanesi'nde kullanıcılara kütüphane kullanımını öğretmek için tanıtım turları düzenlenmekte ve bu konuda kütüphane web sitesinde yer alan bilgiler ile yardımcı olunmaya çalışıımaktadır. BÜ Kütüphanesi kullanıcılarının kütüphane kullanımını hangi yollarla öğrendikleri Tablo 1 'de gösterilmiştir.

Tablo 1: Kullanıcılann BÜ Kütüphanesi'ni Kullanmayı Nasıl Öğrendikleri

\begin{tabular}{|l|r|r|}
\hline Kullanmayı nası öğrendikleri & Sayı & $\mathbf{\%}$ \\
\hline Kütüphanecilerden & 45 & $\mathbf{2 2 , 5}$ \\
\hline Kütüphane tanıtım turundan & 3 & 1,5 \\
\hline Kütüphane web sayfasından & 8 & 4,0 \\
\hline Kendi çabalarıyla & 124 & 62,0 \\
\hline Diğer & 20 & 10,0 \\
\hline Toplam & $\mathbf{2 0 0}$ & $\mathbf{1 0 0 , 0}$ \\
\hline
\end{tabular}

Tablo 1 verileri incelendiğinde, kullanıcılarının büyük bir bölümünün (\% 62,0) BÜ Kütüphanesi'ni kullanmayı kendi çabalarıyla öğrendiği anlaşımaktadır. Bu konuda kütüphanecilerin katkısının \% 22,5 düzeyinde olduğu, tanıtım turlarının ise, çok etkili olamadığı $(\% 1,5)$ görülmektedir. Halkla ilişkilerde teknolojik bir araç olarak son dönemlerde öne çıkan Web hizmetlerinin, kütüphane kullanımını öğretmek açısından fazla katkı sağlayamadığı $(\% \quad 4,0)$ dikkati çekmektedir. Anket sorusunda "diğer" seçeneğini işaretleyen kullanıcıların büyük çoğunluğu, kütüphane kullanımını arkadaşlarından ya da öğretim üyelerinden öğrendiklerini belirtmişlerdir. Kütüphane kullanımını öğretmenin belirli ölçüde halkla ilişkiler olgusu içine girdiği göz önüne alınırsa, kütüphane kullanmayı kendi çabasıyla öğrenenlere ilişkin \% 62,0 oranı, "gerçekleştirilen halkla ilişkiler etkinliklerinin

\footnotetext{
${ }^{2}$ Daha ayrıntılı ve kapsamı değerlendirme ve sonuçlar için bkz. Çağlar (2006) .
} 
kütüphane kullanımını öğrenmeye yeterince katkısının olmadığı" biçiminde yorumlanabilir.

\section{Kullanıcılann BÜ Kütüphanesi'ni Kullanırlarken Güçlük Çekip Çekmedikleri}

Kullanıcıların kütüphaneden yararlanırken güçlük yaşayıp yaşamadıkları kütüphaneye karşı olan düşüncelerini büyük ölçüde belirleyeceği için, halkla ilişkiler açısından önem taşımaktadır. Tablo 2, kullanıcıların BÜ Kütüphanesi'ni kullanırken güçlük çekip çekmediklerine ilişkin verileri içermektedir.

Tablo 2: Kullanıcılann Kütüphaneyi Kullanırlarken Güçlük Çekip Çekmedikleri

\begin{tabular}{|l|r|r|}
\hline Kullanıcılar güçlük çekiyorlar mı? & Sayı & \% \\
\hline Evet & 66 & 33,0 \\
\hline Hayır & 81 & 40,5 \\
\hline Kısmen & 53 & 26,5 \\
\hline Toplam & $\mathbf{2 0 0}$ & $\mathbf{1 0 0 , 0}$ \\
\hline
\end{tabular}

Tablo 2 verilerine göre, kullanıcılarının önemli sayılabilecek bir bölümü kütüphaneyi kullanırken güçlük çekmektedir. Kullanıcıların \% 33 'ünün kütüphaneyi kullanırken tam olarak, \% 26,5'inin de kısmen güçlük yaşadıkları anlaşılmaktadır. \% 60'a yaklaşan bu oran, kütüphaneye sempati duyulmasını olumsuz etkileyecek bir durum olarak yorumlanabilir. Kütüphaneyi rahat kullanamayan, bu konuda sıkıntı çeken kullanıcıların kütüphaneye ilişkin düşünceleri bazı olumsuzluklar içerebilecektir. Kullanıcıların kütüphane kullanımında güçlük yaşamaları, gerçekleştirilen halkla ilişkiler etkinliklerinin yetersizliğini ortaya koymaktadır.

\section{BÜ Kütüphanesinin Isşlem ve Hizmetleri Hakkında Kullanıcı Düşünceleri}

Kullanıcıların BÜ Kütüphanesi'nde gerçekleştirilen işlem ve hizmetlere yönelik genel değerlendirmeleri, bu işlem ve hizmetleri genelde nasıl buldukları onların kütüphaneye ilişkin düşüncelerini doğrudan belirleyici niteliktedir. Kullanıcıların kütüphaneye karşı ilgi, sempati ve güven duymaları, büyük ölçüde onların kütüphanedeki işlem ve hizmetler hakkındaki düşüncelerine bağlı olacaktır. Bu konuda kullanıcı görüşlerini yansıtan veriler Tablo 3'de görülmektedir.

Tablo 3 verilerine göre, BÜ Kütüphanesi'ndeki işlem ve hizmetleri genelde yavaş, zor ve hantal bulan kullanıcı oranı $(\% 6,5)$ ile düşük sayı- 
Tablo 3: Kütüphanenin İşlem ve Hizmetleri Hakkında Kullanıcı Düşünceleri

\begin{tabular}{|l|r|r|}
\hline İşlem ve hizmetler nasıl? & Sayı & \% \\
\hline Hızlı, kolay ve dinamik & 76 & 38,0 \\
\hline Yavaş, zor ve hantal & 13 & 6,5 \\
\hline $\begin{array}{l}\text { Zaman zaman hızlı ve kolay, } \\
\text { zaman zaman yavaş ve zor }\end{array}$ & 111 & 55,5 \\
\hline Toplam & $\mathbf{2 0 0}$ & $\mathbf{1 0 0 , 0}$ \\
\hline
\end{tabular}

labilir. Buna karşın, bu işlem ve hizmetler için açıkça olumlu görüş bildirenlerin oranı da \% 38'de kalmaktadır. Kullanıcıların yarıdan çoğu (\% 55,5) kütüphane işlem ve hizmetleri için olumsuzluk da içeren görüş bildirmektedir. Halkla ilişkiler açısından "kısmen olumlu, kısmen olumsuz" denilebilecek böyle bir seçeneğin olumsuz görüş bildirenlerle birlikte \% 62'ye ulaşan düzeyi dikkat çekmektedir. Kısmen de olsa olumsuzluk içeren duygu ve düşüncelerle bir kuruma bütünüyle ilgi, sempati ve güven duyulabileceği söylenemez.

\section{Kullanıcıların BÜ Kütüphanesi Web Sitesini Kullanmalarının Kütüphane Hizmetlerinden Yararlanmalarına Etkisi}

Kütüphane ile ilgili her türlü bilgilendirme için yoğun olarak kullanılmaya başlanan İnternetin, halkla ilişkilerin son ve popüler aracı olduğu söylenebilir. Bir başka deyişle, son yıllarda kurumlar halkla ilişkiler etkinliklerini gerçekleştirmede İnternet ve dolayısıyla Web sayfalarından yoğun olarak yararlanmaktadır.

Tablo 4: Web Sitesini Kullanmanın Kütüphaneden Yararlanmaya Etkisi

\begin{tabular}{|l|r|r|}
\hline $\begin{array}{l}\text { Web sayfası kullanmanız kütüphaneden } \\
\text { yararlanmanızı olumlu etkiliyor mu? }\end{array}$ & Sayı & $\%$ \\
\hline Evet & 73 & 36,5 \\
\hline Hayır & 20 & 10,0 \\
\hline Kısmen & 44 & 22,0 \\
\hline Kütüphane web sayfasını kullanmıyorum & 63 & 31,5 \\
\hline Toplam & $\mathbf{2 0 0}$ & $\mathbf{1 0 0 , 0}$ \\
\hline
\end{tabular}


Kütüphane web sitesinin kütüphane kullanımını nasıl etkilediğine yönelik veriler, Webin bir halkla ilişkiler aracı olarak işlevselliğini ortaya koymaktadır.

Tablo 4 verilerinde dikkat çeken en önemli nokta, kullanıcıların \% 31,5'inin BÜ Kütüphanesi web sitesini kullanmıyor olmasıdır. Bu veri, BÜ Kütüphanesi'nin web sitesini bir halkla ilişkiler aracı olarak yeterince kullanamadığı biçiminde yorumlanabilir. Web sitesinin olması, kullanıcıların \% 36,5'inin kütüphane kullanımlarını olumlu yönde etkilerken, \% 32'si için olumlu bir etkinin söz konusu olmadığı ya da "kısmen olumlu" olduğu anlaşılmıştır. Genel bir değerlendirme yapılacak olursa, BÜ Kütüphanesi kullanıcılarının yaklaşık üçte biri $(\% 36,5)$ web sitesinden yararlandığını ve bunun kütüphane kullanımlarını olumlu etkilediğini, geriye kalan \% 63,5'luk bölümünün web sayfalarını ya kullanmadığını, ya da kullansa dahi olumlu etkisi olmadığını veya kısmen olumlu etkisi olduğunu söylemektedirler. Dolayısıyla, web sitesinin etkili bir halkla ilişkiler aracı niteliğine yeterince ulaşamadığı anlaşılmaktadır. Oysa yapılan gözlemlere göre BÜ Kütüphanesi web sitesi düzenli olarak güncellenmekte ve kütüphane ile ilgili gelişmeler kullanıcılara duyurulmaktadır.

\section{BÜ Kütüphanesi'ndeki Yer Gösteren Tabela, Yönlendirme ve Kütüphane Kurallarını Anlatan Açıklamaların Yeterliliği}

$\mathrm{Bu}$ anket sorusu kapsamında, BÜ Kütüphanesi'nde halkla ilişkiler araçları olarak kullanılan ve kullanıcıların kütüphaneden rahat yararlanabilmeleri için gerekli olan yer gösterici tabelaların, raflardaki yönlendirmelerin ve kütüphane kurallarını içeren açıklamaların yeterli olup olmadığına yönelik kullanıcı görüşleri incelenmiştir (Bkz. Tablo 5).

Tablo 5: Yer Gösteren Tabela, Raf Yönlendirmeleri ve Kural Açıklamaları

\begin{tabular}{|l|r|r|}
\hline Yer gösteren tabelalar, yönlendirmeler vb. yeterli mi? & Sayı & $\%$ \\
\hline Evet & 86 & 43,0 \\
\hline Hayır & 41 & 20,5 \\
\hline Kısmen & 73 & 36,5 \\
\hline Toplam & $\mathbf{2 0 0}$ & $\mathbf{1 0 0 , 0}$ \\
\hline
\end{tabular}


Tablo 5 verileri, kullanıcıların \% 43'ü önemli halkla ilişkiler araçlarından kabul edilen tabela, yönlendirme levhaları ve kural açıklamalarının yeterli olduğunu söylerken, sözü edilen araçları yetersiz ya da kısmen yeterli bulanların oranı yarıyı aşmaktadır (\% 57). Ciddi bir halkla ilişkiler çalışmasının dikkatini olumsuz ve yarı olumlu/olumsuz seçeneklere yoğunlaştırmak zorunda olması gerektiği daha önce de belirtilmiştir. Çünkü, halkla ilişkiler çalışmaları kurumlar hakkındaki olumsuz düşünceleri olumluya çevirmek için yapılır.

\section{BÜ Kütüphanesi'nin İşlem ve Hizmetlerini Gerçekleştirmede Kullanıcıların Fikirlerini Alma Durumu}

Halkla ilişkilerin en önemli ilke ve uygulamalarından birisi hizmet sunulan kitlelerin kurum ile ilgili fikirlerinin alınmasıdır. Bu uygulama ile kullanıcıların hem kendilerini o kuruma ait hissetmeleri, yani örgüt kültürünün oluşması, hem de onların fikirleri doğrultusunda hizmette yenilikler gerçekleştirilmesi amaçlanmaktadır. Kullanıcıların BÜ Kütüphanesi hizmetleri ile ilgili kendilerinden fikir alınıp alınmadığına dair düşüncelerini içeren veriler Tablo 6'da verilmiştir.

Tablo 6: Kullanıcıların Kütüphane İşlem ve Hizmetleri İle İlgili Fikirlerinin Alınıp Alınmadığı

\begin{tabular}{|l|r|r|}
\hline $\begin{array}{l}\text { Kütüphane işlem ve hizmetleri ile ilgili } \\
\text { olarak fikriniz alınıyor mu? }\end{array}$ & Sayı & $\boldsymbol{\%}$ \\
\hline Evet & 62 & 31,0 \\
\hline Hayır & 65 & 32,5 \\
\hline Kısmen & 73 & 36,5 \\
\hline Toplam & $\mathbf{2 0 0}$ & $\mathbf{1 0 0 , 0}$ \\
\hline
\end{tabular}

Tablo 6 verilerine göre, kullanıcıların yalnızca \% 31'i kütüphane hizmetlerine ilişkin olarak kendilerinden fikir alındığını belirtmiştir. Bu konuda fikrinin alınmadığını söyleyenlerle kısmen alındığını belirtenlerin oranı \% 69' a ulaşmaktadır ki, bu oldukça yüksek bir orandır. Bu durum halkla ilişkiler açısından olumsuz bir görüntüye işaret etmektedir. Bu verilere göre, BÜ Kütüphanesi'nin halkla ilişkiler çalışmaları gereği, kullanıcıların fikirlerini alma konusunda amacına yeterince ulaşamadığı, bu konuda kullanıcılar ile yeterli işbirliğini sağlayamadığı söylenebilir. 


\section{BÜ Kütüphanesi İşlem ve Hizmetleri Hakkında Kullanıcıların Bilgilendirilme Yolları}

BÜ Kütüphanesi'nin hizmetler ve uygulamaları hakkında kullanıcılarını bilgilendirmek amacıyla kullandığı halkla ilişkiler araçları ve gerçekleştirdiği etkinliklerin, kullanıcılar tarafından hangi ölçüde tercih edildiği çalışma açısından değerlendirilmesi gereken bir başka konudur.

Tablo 7: Kullanıcılann Kütüphane Hizmetleri Hakkında Nasıl Bilgilendirildikleri

\begin{tabular}{|l|r|r|}
\hline $\begin{array}{l}\text { Kütüphane hizmetleri hakkında nasıl } \\
\text { bilgileniyorsunuz? }\end{array}$ & Sayı $^{*}$ & $\%$ \\
\hline Kendim kütüphaneye gelerek & 130 & 65,0 \\
\hline İnternet (e-posta yoluyla yapılan duyurular) & 83 & 41,5 \\
\hline Duyuru panosu & 76 & 38,0 \\
\hline Afiş, pankart, el ilanı, broşür & 64 & 32,0 \\
\hline Yüz yüze görüşme, telefon & 22 & 11,0 \\
\hline Fakültelere ve bölümlere yapılan tanıtıcı hizmetler & 20 & 10,0 \\
\hline Radyo, televizyon & 8 & 4,0 \\
\hline Yıllık rapor & 4 & 2,0 \\
\hline Tören, toplantı & 4 & 2,0 \\
\hline
\end{tabular}

Tablo 7'deki verilere göre, kullanıcıların büyük bir bölümü $(\% 65,0)$, kütüphanenin bilgilendirme amaçlı etkinlik ve araçlarından yararlanamamaktadır. Bir başka deyişle, kütüphane kullanıcısının yaklaşık üçte birini hizmetleri ile ilgili olarak bilgilendirebilmektedir.

Bilgilendirme araçları içinde en çok kullanılan ve işlevsel görünen ise İnternettir $(\% 41,5)$. Yani bilgi teknolojisine dayalı halkla ilişkilerin daha etkili olduğu anlaşılmaktadır. Bunu geleneksel diyebileceğimiz duyuru panosu $(\% 38,0)$, afiş, pankart, el ilanı vb. $(\% 32,0)$ izlemektedir. Yüz yüze görüşme $(\% 11,0)$ ile kütüphanenin fakülte ve bölümlere giderek yaptığı tanıtımların $(\% 10,0)$ çok etkili olamadığı, radyo ve televizyon gibi önemli araçlardan ise neredeyse hiç yararlanılamadığı $(\% 4,0)$ görülmektedir. En az etkili halkla ilişkiler aracı olarak da yıllık

* Kullanıcılar birden fazla seçenek işaretlemişlerdir. En çok işaretlenenden en az işaretlenen seçeneğe doğru bir sıralama yapılmıştır. 
raporlar $(\% 2,0)$ ve tören-toplantılar $(\% 2,0)$ yer almaktadır. Kütüphanede halkla ilişkilerin, kullanıcıların üçte birine hiç ulaşamaması olumsuz bir durumken, ulaştıklarında da İnternetin temel araç olması son teknolojik ürünü kullanma açısından olumlu karşılanabilir.

\section{BÜ Kütüphanesi'nin İşlem, Hizmet ve Kuralları Hakkında Kullanıcılarını Bilgilendirme Yeterliliği}

Kullanıcıların, kütüphanenin, hizmetlerine ilişkin yaptığı bilgilendirmeleri yeterli, doyurucu ve işe yarar (işlevsel) bulması halkla ilişkiler açısından önem taşımaktadır. BÜ Kütüphanesi kullanıcılarının kütüphane işlem ve hizmetleri ile ilgili olarak yapılan bilgilendirmeleri yeterli bulup bulmadıklarına ilişkin düşüncelerini içeren veriler Tablo 8'de yer almaktadır.

Tablo 8: Kütüphanesi'nin İşlem, Hizmet ve Kurallar Hakkında Kullanıcıları Bilgilendirme Yeterliliği

\begin{tabular}{|l|r|r|}
\hline $\begin{array}{l}\text { Kütüphanenin işlem ve hizmetleri ile ilgili yaptığı } \\
\text { bilgilendirme yeterli mi? }\end{array}$ & Sayı & $\%$ \\
\hline Evet & 67 & 33,5 \\
\hline Hayır & 43 & 21,5 \\
\hline Kısmen & 90 & 45,0 \\
\hline Toplam & $\mathbf{2 0 0}$ & $\mathbf{1 0 0 , 0}$ \\
\hline
\end{tabular}

Tablo 8 verilerine göre, kullanıcıların sadece üçte biri $(\% 33,5)$ işlem ve hizmetler ile ilgili olarak kütüphanenin yaptığı bilgilendirmeleri yeterli bulmaktadır. Bu güvenle ilgili verilerden daha olumsuz bir durumu ifade etmektedir. Kullanıcıların büyük bir çoğunluğu (\% 45,0) "kısmen" seçeneğini işaretlemiştir. Ancak diğer bir açıdan bakacak olursak, kullanıcıların \% 66,5’i ("kısmen" ve "hayır" diyenlerin toplam oranı) kütüphanenin işlem ve hizmetlere ilişkin olarak verdiği bilgileri ya da yaptığı bilgilendirmeleri tam anlamıyla yeterli bulmamaktadır.

\section{BÜ Kütüphanesi'nin İşlem ve Hizmetleri Hakkında Kullanıcılarını Bilgilendirmesinin Kullanıma Etkisi}

Halkla ilişkilerin genel amacı, kullanıcılarda olumlu düşünceler geliştirerek kurumun kullanımını ve yararlanmayı artırmaktır. Bu kısımda BÜ Kütüphanesi'nin, işlem ve hizmetleri hakkında yaptığı 
bilgilendirmelerin kullanıcıların kütüphane kullanımlarını nasıl etkilediği değerlendirilecektir. Bu bir anlamda halkla ilişkiler çalışmalarının kütüphane açısından yararı olup olmadığını ortaya koyacaktır.

Tablo 9: İşlem ve Hizmetler Hakkında Haberdar Etmenin Kütüphane Kullanıma Etkisi

\begin{tabular}{|l|r|r|}
\hline $\begin{array}{l}\text { Kütüphanedeki işlem vehizmetlerdenhaberdar } \\
\text { edilmeniz kütüphane kullanımınızı nasıl etkiliyor? }\end{array}$ & Sayı & $\%$ \\
\hline Olumlu etkiliyor & 156 & 78,0 \\
\hline Etkilemiyor & 41 & 20,5 \\
\hline Olumsuz etkiliyor & 3 & 1,5 \\
\hline Toplam & $\mathbf{2 0 0}$ & $\mathbf{1 0 0 , 0}$ \\
\hline
\end{tabular}

Tablo 9 verilerine göre, kullanıcıların \% 78'i işlem ve hizmetleri hakkında kütüphane tarafından yapılan bilgilendirmelerin, kütüphane kullanımlarını olumlu yönde etkilediğini belirtmiştir. Oldukça yüksek olan bu oran, halkla ilişkilerin kütüphane açısından ne kadar önemli olduğunu ortaya koymaktadır. Bu tür bilgilendirmelerin kütüphane kullanımlarını etkilemediğini söyleyen \% 20,5'lik kullanıcı grubu bunun nedeni olarak, genelde, "kütüphaneye zaten geldiklerini ve bilgilendirme yapılmasa da geleceklerini" belirtmişlerdir. Kuşkusuz, burada \% 78,0 oranı BÜ Kütüphanesi'nin gerçekleştirdiği halkla ilişkiler çalışmalarının bu oranda etkili olduğu biçiminde yorumlanamaz. Bu tablodaki veriler BÜ Kütüphanesi'nde halkla ilişkilere gereksinim duyulduğu ve halkla ilişkiler çalışmalarının kütüphane kullanımı açısından önemli olduğu biçiminde algılanmalıdır.

\section{BÜ Kütüphanesi'nde Çalışan Personel Hakkında Kullanıcıların Düşünceleri}

Kullanıcıların kütüphane hakkında sahip olacakları düşüncelerin niteliğini belirleyecek başlıca unsurlardan bir tanesi de kütüphane personelidir. Dolayısıyla, personel, kütüphane halkla ilişkiler çalışmalarının üzerinde titizlikle durulması gereken parçalarından birisidir. Personel hakkında olumlu düşünen kullanıcıların kütüphane 
hakkında da olumlu düşünme olasılıkları yüksek olacaktır. Kullanıcıların BÜ Kütüphanesi personeline yönelik düşünceleri Tablo 10'da sunulmuştur.

Tablo 10: BÜ Kütüphane Personeli Hakkında Kullanıcıların Düşünceleri

\begin{tabular}{|l|r|r|}
\hline Personel hakkındaki düşünceler & Sayı & $\%$ \\
\hline $\begin{array}{l}\text { Kullanıcılara her zaman yardımcı } \\
\text { olmaktadıllar }\end{array}$ & 151 & 75,5 \\
\hline Kullanıcılara güler yüzlü davranmaktadırlar & 107 & 53,5 \\
\hline Mesleklerinde bilgili ve tecrübelidirler & 78 & 39,0 \\
\hline $\begin{array}{l}\text { Okuyuculara ilgisiz davranmakta ve yardımcı } \\
\text { olmamaktadırlar }\end{array}$ & 26 & 13,0 \\
\hline Diğer & 11 & 5,5 \\
\hline
\end{tabular}

Tablo 10 verilerine göre, kullanıcıların büyük bölümü $(\% 75,5)$ kütüphane personelinin kendilerine yardımcı olduğunu düşünmektedir. Kullanıcıların \% 53,5'u personelin güler yüzlü davrandığını ve \% 39'uda onların mesleklerinde bilgili ve deneyimli olduklarını belirtmektedirler. Yani, kullanıcıların büyük bir çoğunluğu kütüphane personeli hakkında olumlu düşüncelere sahiptir. Personel hakkında olumsuz düşünenlerin oranı ise son derece düşüktür $(\% 13,0)$. Anket sorusunda "diğer" seçeneğini işaretleyen kullanıcıların büyük çoğunluğu, açıklamalarında personelin bazen ilgili, bazen de ilgisiz olduklarını belirtmişlerdir. Bu verilere göre, BÜ Kütüphanesi'nde halkla ilişkiler açısından buraya kadar incelenen unsurlar içinde en olumlusu personeldir.

\section{BÜ Kütüphanesi'nin Kullanıcılarda Yarattığı Değişiklik}

Kütüphane hakkında belli bir bilince sahip kullanıcıların, onun yaşamlarını nasıl etkiledikleri konusundaki düşünceleri de halkla ilişkiler açısından incelenmesi gereken bir konudur. Bu konudaki kullanıcı düşünceleri Tablo 11'de verilmiştir: 
Tablo 11: BÜ Kütüphanesi'nin Kullanıcılarda Yarattığı Değişiklik

\begin{tabular}{|l|r|r|}
\hline Kütüphane yaşamınızı nasıl etkiliyor? & Sayı & \% \\
\hline $\begin{array}{l}\text { Eğitim yaşamımı ve entelektüel gelişimimi } \\
\text { olumlu etkiliyor }\end{array}$ & 146 & 73,0 \\
\hline $\begin{array}{l}\text { Eğitim yaşamıma ve entelektüel gelişimime } \\
\text { herhangi bir etkisi olmuyor }\end{array}$ & 48 & 24,0 \\
\hline Diğer & 6 & 3,0 \\
\hline Toplam & $\mathbf{2 0 0}$ & $\mathbf{1 0 0 , 0}$ \\
\hline
\end{tabular}

Tablo 11 verilerine göre, kullanıcıların büyük çoğunluğu $(\% 73,0)$ kütüphanenin eğitim yaşamlarını ve entelektüel gelişimlerini olumlu etkilediğini belirtmiştir. Bu kütüphane adına olumlu bir tablodur. Bu tablo önceki tablolarda verileri sunulan ve kullanıcıların kütüphane hakkında olumsuz, ya da kısmen olumlu düşüncelere sahip olduğu yönündeki sonuçlarla çelişkili gibi görünmektedir. Ancak, kütüphanenin kullanıcılara etkisi ile kullanıcıların kütüphane hakkında düşünceleri aynı olgular değildir. Bir başka deyişle, kullanıcılar bir kütüphanenin kendileri için kuramsal olarak önemli ve yararlı olduğunu düşünmekle birlikte, onun hakkında çeşitli nedenlerle olumsuz düşüncelere sahip olabilirler.

\section{BÜ Kütüphanesi Hakkında Kullanıcıların Genel Düşünceleri}

Tablo 12'de kullanıcıların BÜ Kütüphanesi'ne yönelik genel düşünceleri yansıtılmıştır. Kütüphane hakkında kullanıcıların sahip olduğu genel düşünce, kütüphanenin halkla ilişkiler çalışmalarının geldiği noktayı ve elde ettiği başarının düzeyini göstermesi açısından son derece önemli görünmektedir. Soruda verilen seçenekler genelde kullanıcıların kütüphane hakkında olumlu düşünüp düşünmediklerini ortaya koymak amacıyla oluşturulmuştur. Daha açık bir deyişle, kullanıcıların işlem ve hizmetlere yönelik yeterlilik-yetersizlik düşüncelerini, kütüphaneye olan güven duygusunu; estetik ve sempatik bulup bulmamalarını ifade edecekleri düşünülmüştür.

Tablo 12 verilerine göre, kütüphaneyi yeterli, estetik ve sempatik bulan kullanıcıların oranı yalnızca \% 15'tir. Bu son derece düşük bir orandır. Kütüphane hakkında olumsuz düşünce bildiren kullanıcılarla (\% 21,5), kısmen olumlu düşünce bildirenlerin oranı (\% 63,5) birleştirildiğinde \% 85’i bulmaktadır. Yoğunluğun "kısmen" seçeneğinde 
oluştuğu görülmektedir. Kullanıcıların büyük çoğunluğu kütüphaneye kısmen güven-ilgi duymakta ve onu sempatik bulmaktadır.

Tablo 12: Kullanıcıların Kütüphane Hakkındaki Genel Düşünceleri

\begin{tabular}{|l|r|r|}
\hline Kütüphane hakkında genel düşünce & Sayı & $\mathbf{\%}$ \\
\hline Olumlu (Yeterli, estetik ve sempatik vb.) & 30 & 15,0 \\
\hline Olumsuz (Yetersiz, estetik - sempatik değil vb.) & 43 & 21,5 \\
\hline Kısmen olumlu (Kısmen yeterli, estetik ve sempatik vb.) & 127 & 63,5 \\
\hline Toplam & $\mathbf{2 0 0}$ & $\mathbf{1 0 0 , 0}$ \\
\hline
\end{tabular}

\section{Sonuç ve Öneriler}

Araştırmada elde edilen bulgulara dayanarak şu sonuçları sıralamak olanaklıdır:

1. BÜ Kütüphanesi kullanıcıları, kütüphane kullanmayı büyük ölçüde kendi çabalarıyla öğrenmektedirler. Bu konuda kütüphanecilerin katkısı ve kütüphane tanıtım turları etkili olamamaktadır. Son dönemlerde en önemli teknolojik araç olarak kabul edilen Web hizmeti ise anlamlı bir katkı sağlayamamaktadır. Kullanıcılar kendi çabaları dışında kütüphaneyi arkadaşlarından ya da öğretim üyelerinden yardım alarak kullanmayı öğrenmektedirler. Bu durumda, kütüphanecilerin tutumu, kütüphane tanıtım turları ve web sitesi halkla ilişkiler aracı olarak kabul edildiğinde, halkla ilişkiler açısından bir yetersizlik ortaya çıkmaktadır. Bir başka deyişle, halkla ilişkiler araç ve çalışmaları kullanıcıların BÜ Kütüphanesi'ni kullanmayı öğrenmelerinde yeterince etkili olamamaktadır.

2. BÜ Kütüphanesi kullanıcıları kütüphaneden yararlanırken genelde güçlük çektiklerini ifade etmektedirler. Kütüphanenin halkla ilişkiler çerçevesinde gerçekleştirdiği çalışmalar, kullanıcıların bu sorunu aşmalarında genelde yeterli olamamaktadır. Bu durumun ise, halkla ilişkiler çalışmalarının temel hedeflerinden olan "kuruma güven duygusunu" olumsuz etkilediği düşünülmüştür.

3. Kullanıcılar kütüphanenin gerçekleştirdiği işlem ve hizmetler hakkında kısmen olumlu düşünmektedirler. Diğer bir deyişle, kullanıcılar kütüphane işlem ve hizmetlerini zaman zaman olumlu (hızlı, kolay ve dinamik), zaman zamanda olumsuz (yavaş, zor ve 
hantal) bulmaktadırlar. BÜ Kütüphanesi tarafından gerçekleştirilen halkla ilişkiler çalışmaları kullanıcılarda işlem ve hizmetler hakkında kısmen olumlu düşünceler yaratabilmiştir.

4. BÜ Kütüphanesi kullanıcıları son dönemin önemli halkla ilişkiler araçlarından biri olarak kabul edilen kütüphane web sitesini yeterince kullanmamaktadırlar. Webi kullananlar için ise sayfanın kütüphaneden yararlanmaya anlamlı bir etkisi olamamaktadır. Dolayısıyla, kullanıcılar BÜ Kütüphanesi Web hizmetlerinden etkili bir halkla ilişkiler aracı olarak yeterince yararlanamamaktadır. Ancak, bu durum düzenli olarak güncellenen ve gerekli bilgileri içeren kütüphane web sitesinin yetersizliğinden veya erişim sorunundan kaynaklanma- maktadır. Ancak, Webe erişim ile ilgili bu sorun, web sitesinin halkla ilişkiler açısından etkili bir biçimde kullanılamama sonucuna neden olmaktadır.

5. BÜ Kütüphanesi geleneksel halkla ilişkiler araçlarını (tabela, levha, yönlendirmeler vb.) yeterince ve etkili bir biçimde kullanamamaktadır. Bir önceki sonuçta ifade edildiği gibi, web sitesine ilişkin yetersizlik ile burada ortaya çıkan geleneksel halkla ilişkiler araçlarının kullanımındaki sınılııı, halkla ilişkiler araçlarının kullanımı açısından genel bir sorunun söz konusu olduğunu göstermektedir.

6. BÜ Kütüphanesi, halkla ilişkilerde son derece önemli olan "hizmetlerin geliştirilmesinde kullanıcıların fikirlerinin alınması" ilkesini uygulayamamakta, diğer bir deyişle, hizmetlerin planlanması ve geliştirilmesi çalışmalarında kullanıcılarla yeterince "işbirliği" yapamamaktadır. Kütüphanede bu amaçla yerleştirilen istek-şikâyet kutusu, şikâyet defteri, anket vb. araçları işlevsel olamamaktadır.

7. BÜ Kütüphanesi tarafından halkla ilişkiler çerçevesinde yapılan bilgilendirme çalışmaları, kullanıcıların kütüphane kullanımlarını olumlu etkilemektedir. Bu sonuç, bir kurum için ve dolayısıyla BÜ Kütüphanesi için halkla ilişkiler çalışmalarının ne kadar önemli olduğunu ortaya koymaktadır. Bu durumda, önceki maddelerde sunulan ve kütüphanenin halkla ilişkiler çalışmalarında yeterince güvenilirlik yaratamadığı yönündeki sonuç ile ne kadar önemli bir kayıp yaşandığı anlaşılmaktadır. 
8. Başarılı halkla ilişkilerin önemli unsurlardan birisi olan personelin kullanıcılara karşı davranışları son derece olumlu görünmektedir, Kütüphanede hizmetlerine yönelik yetersizlikte (veya kısmi yetersizlikte) personelden kaynaklanan bir sorun bulunmamakta, personel kullanıcılara son derece olumlu davranmaktadır.

9. $\mathrm{Bu}$ çalışmada saptanan eksikliklerine/yetersizliklerine ve kullanıcıların bunu belirtmelerine karşın, kütüphane, kullanıcıların eğitim ve entelektüel yaşamlarına olumlu katkıda bulunmaktadır. Ancak, bu durum, onların kütüphane hakkında olumlu düşüncelere sahip olmalarına da yetmemektedir. Nitekim elde edilen bir başka sonuca göre, kullanıcıların büyük çoğunluğu kütüphaneyi genelde yeterli, estetik ve sempatik bulmamaktadır. Ancak, açık uçlu bir soru ile kullanıcıların, sorulan sorular dışında dile getirmek istedikleri kütüphane hakkındaki görüşleri öğrenilmeye çalışıımıştır. Kullanıcılar, bu soru çerçevesinde mekânsal yetersizlik, kaynak yetersizliği, rafların düzeni, tarama bilgisayarları ve gürültü konusunda sorunları olduğunu belirtmişlerdir. Kütüphane hakkında bu nitelikte düşüncelere sahip bir kullanıcı kitlesine uygulanan halkla ilişkiler çalışmalarının başarısı da sınırlı olmuştur.

Araştırmada elde edilen sonuçlar çerçevesinde bazı öneriler geliştirilebilir.

1. BÜ Kütüphanesi kullanıcılara kütüphaneden daha iyi yararlanabilmeyi öğretmede etkinliğini artırmalı ve halkla ilişkiler araçlarını verimli biçimde kullanmalıdır. Bu amaçla kütüphane tanıtım turları ve web sitesi cazip hale getirilmelidir. Bir başka deyişle, duyuru panosu, afiş, broşür, İnternet, üniversite televizyonu vb. halkla ilişkiler araçlarından uygun olanlar tercih edilmelidir.

2. BÜ Kütüphanesi halkla ilişkiler çalışmalarının yeterince etkili olamamasının temel nedenlerinden birisi olarak saptanan mekânsal yetersizlik en kısa sürede çözüme kavuşturulmalıdır. Bunun için en uygun çözüm yeni ve bağımsız bir kütüphane binası inşa edilmesidir. Halen kullanılmakta olan kütüphane binasına zaman zaman eklemeler ve düzenlemeler yapılmasına karşın daha fazla değişikliğe olanak bulunmadığı söylenebilir. Var olan binanın, daha iyi aydınlatılması, ısıtılması, havalandırılması ve 
mobilyalarının yenilenmesi yanında tuvaletlerin kullanıcılara açılması, uygun yerlere estetik/görsel materyallerin (tablo, heykel vb.) yerleştirilmesi vb. iç tasarım değişiklikleri düşünülebilir. Ancak, bunlar konferans, toplantı ve sergi salonları, kantin, personel mutfağı, uygun personel ofisleri gibi alanların olmaması sorununa çözüm getirmeyecektir. Ayrıca, personel ofislerinin kullanıcı alanlarıyla iç içe olmasından kaynaklanan zorlukların da bu mekânda giderilmesi zor görünmektedir. Bu nedenle, yeni bir kütüphane binası önerimizi bir kez daha vurgulamakta yarar görmekteyiz.

3. BÜ Kütüphanesi, kullanıcıların, kısmen olumlu düşündükleri kütüphane işlem ve hizmetlerini biraz daha kolaylaştırmaya ve hızlandırmaya çalışmalıdır. Gerçekte bu sorunun da mekân yetersizliğinden kaynaklandığı söylenebilir. Bu çerçevede, örneğin kullanıcıların kendi kendilerine kaynak ödünç alma-verme işlemlerini gerçekleştirebilecekleri makineler (shelf-check) yerleştirilebilir, tarama bilgisayarları yenilenerek sayıları artırılabilir.

4. Kütüphane web sitesi halkla ilişkiler çalışmaları açısından daha etkin ve kullanışı hale getirilmeli, özellikle kullanıcılara duyurulması ve yeniliklerden haberdar edilmeleri gerekmektedir.

5. Kullanıcıları kütüphane hizmetleri hakkında bilgilendirirken çeşitli halkla ilişkiler araçlarından yararlanılabilir. İnternet, Web sayfası, eposta gibi yeni halkla ilişkiler araçlarının yanı sıra duyuru panosu, afiş, pankart, el ilanı, broşür, yüz yüze görüşme, telefon, televizyon, yıllık rapor, tören, toplantı gibi klasik araçları da daha verimli biçimde ve görsel açıdan zenginleştirilerek kullanılmalıdır. İstek-şikâyet kutusu, şikâyet defteri ve anket gibi araçlara kullanıcıların ilgilerinin artırılmasına çalışılmalıdır. Ayrıca üniversite içinde, kütüphane ile ilgili toplantılar düzenlenmeli, kütüphanenin etkinliklerinin radyo ve televizyon gibi araçlarla duyurulması sağlanmalıdır. Kütüphanenin girişinde bulunan duyuru panosunun daha etkileyici ve dikkat çekici olması için çeşitli yenilikler yapılmalıdır. Yüz yüze görüşme ve telefon gibi halkla ilişkileri geliştirecek araçlarla kullanıcılarla sürekli iletişim kurulmalıdır. Kütüphanenin hizmetleri ile ilgili afişler, pankartlar, el ilanları vb. hazırlanarak, üniversitenin çeşitli fakültelerine, bölümlerine ve 
kafeteryalara asılmalıdır. Kütüphanenin e-posta yoluyla yaptığı duyuru ve tanıtım hizmetlerini artırması gerekmektedir.

6. Halkla ilişkiler açısından önemli olan kütüphane içi bilgilendirme ve yönlendirme levhaları daha yoğun biçimde kullanılmalıdır.

7. BÜ Kütüphanesi'nde daha çok oryantasyon programı ve tanıtıcı turlar düzenlenmelidir.

8. Kütüphane hizmetleri planlanırken ve geliştirilirken kullanıcı düşünceleri mutlaka alınmalıdır. Halkla ilişkiler açısından gerekli olan bu yaklaşım kullanıcıların kütüphaneye karşı olan düşüncelerini olumlu etkileyecek, onlarda güven ve ait olma duygusu yaratacaktır. Önerilerin alınmasında geleneksel ve teknolojik halkla ilişkiler araçlarından yararlanılabilinir.

9. Halkla ilişkiler çalışmalarının temel gerekliliklerinden olan kullanıcıların kütüphane işlem ve hizmetleri hakkında bilgilendirilmeleri konusunda daha yoğun çaba harcanmalıdır. Bu amaçla klasik halkla ilişkiler araçlarının yanı sıra, özellikle e-posta ve Web sayfaları da etkin bir biçimde kullanılmalıdır. Halkla ilişkiler çalışmalarının temel hedeflerinden birisi de kullanıcıların yapılan bilgilendirmelere inanmalarını sağlamak olmalıdır. Çalışmada elde edilen sonuçlara göre, bilgilendirmelere yönelik bir güven eksikliği saptanmış ve bu durumun giderilmesi öncelik kazanmıştır.

10. Çalışmanın sonuçları arasında yer alan ve halkla ilişkilerin temel ilkeleri olarak belirlediğimiz, kullanıcıda kütüphaneye karşı ilgi, güven ve sempati yaratan "kullanıcının bilgi gereksinimlerini karşılama" konusunda, kütüphane daha çok çaba harcamalıdır. Kütüphane kullanıcılarının bilgi gereksinimlerini tam anlamıyla karşılayamadığı sürece, halkla ilişkiler uygulamalarının etkisi sınırlı kalacaktır. Bilgi gereksinimlerinin karşılanması, halkla ilişkiler açısından alt yapısal koşul niteliği taşımakta ve halkla ilişkiler çalışmalarının başarısını belirlemektedir. Bilgi gereksinimlerinin karşılanması için mevcut yetersizliklerin giderilmesi ise, kütüphane işlem ve hizmetlerinin bir bütün olarak geliştirilmesinden geçmektedir. Ancak, halkla ilişkiler açısından önemli olan, kullanıcıların, bilgi gereksinimlerinin karşılanması konusunda kütüphane için olumlu düşüncelere sahip olmalarıdır. Bu nokta ile ilgili somut olarak kütüphanedeki mekânsal yetersizliğin 
giderilmesi, dermenin güçlendirilmesi, raf düzeninin daha iyi hale getirilmesi, tarama bilgisayarlarının artırılması ve gürültünün azaltılması konusunda önlemler alınması önerilebilir.

11. BÜ Kütüphanesi'nin halkla ilişkiler çalışmalarında personelden kaynaklanan önemli bir sorun saptanmamış olmasına karşın, personel halkla ilişkiler konusunda düzenli aralıklarla hizmet içi eğitimden geçirilmelidir. Ayrıca, halkla ilişkiler konusunda başarılı çalışmaları bulunan diğer kütüphanelerin deneyimlerinden yararlanarak ortak çalışmalar ve işbirliği geliştirilmelidir.

12. Kütüphanede halkla ilişkiler ya da bilgi ve belge yönetimi bölümlerinden mezun bir uzmanın halkla ilişkiler çalışmalarından sorumlu olarak görevlendirmesi yerinde olacaktır.

Sonuç olarak, halkla ilişkiler çalışmaları üniversite kütüphanelerinde kaliteyi yükselten ve kütüphanenin hedeflerine ulaşmasına önemli katkılar sağlayan etkinlikler bütünüdür. Üniversite kütüphanesinin bu aracı etkin olarak kullanması günümüz koşullarında zorunlu görünmektedir. Ayrıca, BÜ Üniversitesi Kütüphanesi'nde çalışan personelin kütüphanedeki halkla ilişkiler uygulamaları konusundaki durum ve düşüncelerinin araştırılması da bir başka çalışmanın konusu olarak önerilebilir.

\section{Kaynakça}

Arda, S. (2000). Tanıtım kütüphanemiz. Başkent'in Sesi, 3(7): 12.

Asna, M. A. (1997). Halkla ilişkiler. İstanbul: Sabah Kitapçılık San. ve Tic. A.Ş.

Bıçakçı,I. (1998). Iletişim ve halkla ilişkiler. Ankara: MediaCat Yayınları.

Biber, A. (2004). Halkla ilişkilerde teorik bir çerçeve (E. Şen, Yay. Haz.). Ankara: Vadi yayınları.

Black, S. (1993). The essentials of public relations [Halkla ilişkilerde esaslar]. London: Kogan .

Budak, G. ve Budak, G. (2004). Halkla ilişkiler (davranışsal bir yaklaşım). (4. bs.). İzmir: Barış yayınları.

Çağlar, N.G. (2006). Üniversite kütüphanelerinde halkla ilişkiler ve Başkent Üniversitesi Kütüphanesi. Ankara: Hacettepe Üniversitesi. Yayımlanmamış yüksek lisans tezi. 
Çınar, Ş. (1998). Başkent Üniversitesi Kütüphane ve Dokümantasyon Daire Başkanlığı TS-EN-ISO 9000 çalışmaları. Türk Kütüphaneciliği, 12(1), 70-72.

Çıngı, H. (1990). Örnekleme kuramı. Ankara: Hacettepe Üniversitesi.

Emezi, H.O. (1972). Public relations in university libraries [Universite kütüphanelerinde halkla ilişkiler]. Nigerian Libraries, 8, 29-33.

Fındık, E. (1985). Türkiye'deki halk kütüphanelerinde halkla ilişkiler. Doktora tezi. Ankara: Hacettepe Üniversitesi.

Fındık, E. (1988). Kütüphanecilikte halkla ilişkiler. Türk Kütüphaneciliği, II, 2: 69-73.

Ford, V. (1985). PR: The state of public relations in academic libraries [PR: Akademik kütüphanelerde halkla ilişkilerin durumu]. College and Research Libraries, 46, 5: 395-401.

Guinchat, C. ve Meneoe, M. (1990). Bilgi ve dokümantasyon çalışma tekniklerine genel giriş (S. Taner, Çev.). Ankara: Kültür Bakanlığı.

Harrison, S. (1995). Public relations: An introduction [Halkla ilişkiler: giriş]. London: Routledge.

Jefkins, F. (1974). Marketing and relation public, media planning [Pazarlama ve halkla ilişki, medya planlaması]. Oxford: Pergamon Press.

Kayan, Y. (1996). Üniversite kütüphanelerinde halkla ilişkiler ve Türkiye'de durum. Yüksek lisans tezi, Gazi Üniversitesi, Ankara.

Külcü, Ö. (2005). Kamu üniversitelerinde kalite yönetimi ve kalite sistem dokümantasyonu çerçevesinde belge yönetimi. Doktora tezi, Hacettepe Üniversitesi, Ankara.

Lesly, P. (1989). The nature and role of public relations [Halkla ilişkilerin rolü ve yapısı]. Lesly's handbook of public relations and communications. (4 ${ }^{\text {th }}$ ed.) Chicago: Probus Publishing, 3-19

Marston, J.E. (1963). The nature of public relations [Halkla ilişkilerin yapısı]. New York: Mc Graw-Hill Book Company.

Peltekoğlu, F.B. (1993). Halkla ilişkilere giriş. İstanbul: Marmara Üniversitesi.

Sabuncuoğlu, Z. (2004). İşletmelerde halkla ilişkiler (6. bs.). Bursa: Ezgi Kitabevi.

Simmons, M.L. (1989). Public relations and the library [Halkla ilişkiler ve kütüphane]. Intellectual Freedom Manual içinde (ss.187-191) Chicago: ALA. 
Sönmez, P. (2000). Üniversite kütüphanelerinde halkla ilişkiler ve Bilkent Üniversitesi Kütüphanesi. Yüksek lisans tezi, Ankara: Ankara Üniversitesi.

Şen, S. ve Çerçi, M. (1976). Halkla iliş̧kiler (2.bs.). Ankara: DPT yayınları.

Tengilimoğlu, D. ve Öztürk, Y. (2004). İşletmelerde halkla ilişkiler. Ankara: Seçkin Yayıncılık.

Tortop, N. (2003). Halkla ilişkiler (8. bs.). Ankara, Yargı.

TS-EN-ISO 9001:2000 Kalite Yönetim Sistemleri: Temel eğitim notu (2001). Ankara: TSE.

Tunçkanat, H. (1989). Araştırma olgusu ve üniversite kütüphanelerinin üniversite içindeki yeri. Türk Kütüphaneciliği, 3, 189-195.

Yapar, B.M. (1999). Devlet İstatistik Enstitüsü'nde halkla ilişkiler uygulaması. Ankara: Devlet İstatistik Enstitüsü Uzmanlık Tezi.

Yılmaz, E. (1996). Kütüphanecilikte halkla ilişkiler ve kitle iletişim araçları. Ankara: Hacettepe Üniversitesi. Yüksek lisans tezi 